\title{
Mixed citation
}

Public Domain

\section{Source}

Open Research Glossary

A textual, bibliog raphic description of a work that is cited within text. 